\title{
Detection of human mammaglobin mRNA in breast cancer cells among Vietnamese women
}

\author{
Hien Minh Nguyen' \\ Minh Quang Dao² \\ 'Department of Biochemistry, Thanh \\ Nhan Hospital, Hanoi, Vietnam; \\ ${ }^{2}$ Department of Oncology, Thanh \\ Nhan Hospital, Hanoi, Vietnam
}

This article was published in the following Dove Medical Press journal: Breast Cancer - Targets and Therapy

Background: Detecting circulating tumor cells (CTCs) is a promising approach for evaluating the progression of occult metastases as well as the efficacy of treatment therapies among patients with breast cancer. A real-time reverse transcriptase polymerase chain reaction (RT-PCR) technique has been proposed for detecting CTCs due to its high sensitivity. In this study, we aimed to validate the RT-PCR technique for human mammaglobin (hMAM) mRNA detection among Vietnamese women with breast cancer.

Patients and methods: Peripheral blood samples and breast cancer tissues from 43 patients suffering from breast cancer and 21 patients with fibroids were obtained. Real-time RT-PCR and gene sequencing techniques were employed to detect $h M A M$ gene in CTCs of breast cancer cell lines and cancer tissues.

Results: $h M A M$ mRNA transcription was detected in 36 out of $43(83.7 \%)$ breast cancer tissues and in blood of 23 out of $43(53.5 \%)$ breast cancer patients, while it was detected in only $9.5 \%$ out of tissues and $0 \%$ of the blood of fibrosis patients. hMAM mRNA in the peripheral blood of breast cancer patients increased with tumor size, stage of cancer and distant metastasis $(P<0.05)$. No difference in the expression of $h M A M$ mRNA was found in breast cancer tissue regarding age, distant metastasis, lymph node, stages of cancer and histopathology $(P>0.05)$.

Conclusion: The study highlighted the expression of $h M A M$ mRNA in breast cancer cells and tissues. This reveals the overall picture of the replication of $h M A M$ mRNA in breast cancer, suggesting the role of $h M A M$ mRNA in breast cancer molecular pathology.

Keywords: human mammaglobin mRNA, $h M A M$ mRNA, breast cancer, circulating tumor cell, CTC, women, Vietnam

\section{Introduction}

Breast cancer is a common health issue among women in Vietnam. A recent report estimates that the age-standardized incidence rate of breast cancer in Vietnamese women increased significantly from 13.8 to 29.9 per 100,000 women between 2000 and 2010, which means that there would be 12,533 new breast cancer cases annually nationwide. ${ }^{1}$ Early screening, detection and treatment are thus vital for the reduction of this disease burden. ${ }^{2}$ Recently, detecting circulating tumor cells (CTCs) has been found to be a promising approach for evaluating the progression of occult metastases as well as the efficacy of treatment therapies among patients with breast cancer. ${ }^{3} \mathrm{CTCs}$ flow in the patients' peripheral blood stream and are believed to be a mediator of distant metastases of breast cancer to other organs. ${ }^{4-6}$ Thus, identifying CTCs in the peripheral blood of breast cancer patients can have critical implications in assisting oncologists to determine appropriate therapeutic methods.
Correspondence: Hien Minh Nguyen Thanh Nhan Hospital, 42 Thanh Nhan Street, Hai Ba Trung District, Hanoi, 100000 , Vietnam

Tel +84949595886

Email minhhien.thanhnhan@gmail.com 
A number of methods have been tested to detect CTCs, such as cytogenetics, morphology and flow cytometry, but they have shown limited diagnostic values. ${ }^{7}$ Recently, a realtime reverse transcriptase polymerase chain reaction (RTPCR) method has been proposed for the detection of CTCs due to its high sensitivity. ${ }^{8-10}$ This technique uses specific expression of marker genes for different tissues or tumors in order to detect the existence of these tumor cells. ${ }^{3}$ It has been previously used to identify circulating breast cancer cells among patients with metastates. ${ }^{10,11}$

Markers for RT-PCR may vary across clinical settings, of which human mammaglobin (hMAM) mRNA is one of the most specific markers for detecting CTCs via peripheral blood in breast cancer patients. ${ }^{12,13}$ hMAM is a glycoprotein with 93 amino acids and member of secretoglobin-uteroglobin family. ${ }^{3,14}$ Its expression and overexpression are primary in mammary tissues and breast cancer tissues, respectively. ${ }^{3,14}$ However, to date, there is a lack of data about the expression of $h M A M \mathrm{mRNA}$ in the Vietnamese population. Our hypothesis is that there is a significant difference in the expression of $h M A M$ mRNA between breast cancer tissue and fibrosis tissue, as well as between breast cancer tissue and peripheral blood of breast cancer patients. In this study, we aimed to validate the RT-PCR technique for $h M A M$ mRNA among Vietnamese women with breast cancer.

\section{Patients and methods}

\section{Study design and sampling}

A total of 43 patients with confirmed breast cancer in all stages were recruited at the time of diagnosis at the K Hospital - the largest oncology hospital in Vietnam. They were excluded if they had tumors in other organs, were treated by any therapies and did not accept to participate. In addition, 21 fibroid patients in the same hospital were also invited to participate in the study. A convenient sampling technique was used to recruit patients.

\section{Blood samples}

Five milliliters of peripheral blood in both breast cancer patients and fibroid patients was obtained and stored in EDTA. The blood samples were centrifuged at 4,000 rpm for 20 minutes. After that, the plasma was removed and the white blood cells were collected to enrich the cells, including breast cancer cells. Samples were stored at $4^{\circ} \mathrm{C}$ and processed immediately after being drawn.

\section{Tissue samples}

About 20-30 mg of tissue samples were obtained from those patients from whom blood was drawn, after they had a surgery to remove the tumor. Samples were then stored in sterile vials at $-80^{\circ} \mathrm{C}$ until RNA separation.

\section{Breast cancer cells}

MCF-7, BT-474, KPL-4 and MDA-MB231 cells were cultured in DMEM with high glucose (Thermo Fisher Scientific, Waltham, MA, USA) $+10 \%$ FBS (Thermo Fisher Scientific) $+1 \%$ penicillin/streptomycin (Thermo Fisher Scientific) $+2 \mathrm{mM}$ l-glutamine. These cells were counted before the experiment. These cell lines were purchased from Vietnam Academy of Science and Technology. They were counted using the following steps:

- We took $90 \mu \mathrm{L}$ of cell culture fluid $+10 \mu \mathrm{L}$ of trypan blue which were incubated at room temperature for about 3-4 minutes. Then, we took $10 \mu \mathrm{L}$ of cells after dyeing with trypan blue and placed them in a Neubauer counting chamber.

- We counted the number of living cells in each $1 \mathrm{~mm}^{2}$. Living cells were not stained and the total number of cells was calculated according to the following formula:

1. Cell concentration in the initial fluid $=$ total number of cells counted (in $1 \mathrm{~mm}^{2}$ cells)/count times $\times 10^{4} \times$ dilution $\times(10 / 9)($ cells $/ \mathrm{mL})$

2. Total cell count $=$ cell concentration in the initial fluid $\times$ number of cell fluids (cells)

\section{RT-PCR procedure}

Tumor cells in the blood were obtained by centrifuging the blood samples at 4,000 rpm for 20 minutes. Cells in breast cancer tissues were taken after the tumor removal surgery. Samples were stored at $4^{\circ} \mathrm{C}$ and sent immediately to the laboratory for total RNA extraction. Total RNA from breast cancer cells in the peripheral blood and tissues was processed using the Mini Kit (Qiagen Kit Rneasy; Qiagen, Hilden, Germany). The purity and concentration of total RNA were checked by using RNA absorption spectrum on NanoDrope-1000. The purity depends on the ratio of OD at $260 \mathrm{~nm}$ to OD at 280 $\mathrm{nm}$, and the ratio ranging from 1.7 to 2.0 is acceptable for considering purity.

cDNA creation (RT-PCR) was done using the Invitrogen ${ }^{\text {TM }}$ SuperScript ${ }^{\mathrm{TM}}$ II Reverse Transcriptase with up to $1 \mathrm{pg}$ of total RNA. Because the total RNA samples extracted from the tissues and the blood samples were not similar, it was necessary to adjust the process from total RNA to cDNA in order to ensure that the imports for real-time PCR had equivalent total RNA (about $100 \mathrm{ng}$ ). First, we used about $100 \mathrm{ng}$ of total RNA and mixed it with RNase-free water to obtain a volume of $6 \mu \mathrm{L}$ per tube. One microliter of the reaction mix and $1 \mu \mathrm{L}$ 
or random hexamers were also added and incubated at $65^{\circ} \mathrm{C}$ for 5 minutes; then, this combination was kept on ice for 1 minute. Finally, $10 \mu \mathrm{L}$ of buffer and $2 \mu \mathrm{L}$ of enzyme were added to reach a volume of $20 \mu \mathrm{L}$ per tube.

cDNA was synthesized in three thermal cycles: $25^{\circ} \mathrm{C} / 10$ minutes, $50^{\circ} \mathrm{C} / 50$ minutes, and $85^{\circ} \mathrm{C} / 5$ minutes. The cDNA product was stored at $-20^{\circ} \mathrm{C}$ according to the manufacturer's guideline (Thermo Fisher Scientific). RT-PCR was performed with the primers for $h M A M, G A P D H$. GAPDH is a standard gene. We implemented PCR reaction with $G A P D H \mathrm{~F} / \mathrm{R}$ primer to test the quality of synthesized cDNA. After confirming that good-quality cDNA was synthesized, PCR was conducted with $h M A M$ primer. A standard curve was built by using breast cancer samples with a certain number of cells $\left(2 \times 10^{4}\right)$. We performed PCR for cDNA, which was synthesized from sample and breast cancer cells. $h M A M$ primers (Table 1) were used to check this process.

\section{PCR and sequencing}

PCR from cDNA was processed with $h M A M$ and $G A P D H$ primers. PCR product was checked by electrophoresis on $1 \%$ agarosegel. Several samples were sequenced to confirm that the cloned genes were $h M A M$ genes.

\section{Real-time PCR}

Real-time PCR with $h M A M$ primer was conducted using Roche's SYBR Green kit. Copies obtained from PCR products were computed as follows:

$$
\begin{gathered}
\mathrm{X}(\mathrm{g}) / \mu \mathrm{L} \text { DNA } /[\text { length } \mathrm{RNA} \times 2 \times 340] \times 6.022 \times 10^{23}=\mathrm{Y} \\
\text { copies } / \mu \mathrm{L}
\end{gathered}
$$

where 340 is the molecular weight of a nucleotide and $6.022 \times 10^{23}$ is the number of molecules in 1 mole of the substrate.

Number of original cDNA $=$ number of copies obtained from PCR/2n ( $\mathrm{n}$ is the number of PCR cycles)

Standard curves were built by calculating the number of cDNA in each tube after diluting at the rate
10/100/1.000/10.000. SYBR Green, the amplified response could be seen through the emitted fluorescence signal, which is attached to the double-stranded DNA from the start to the end of the process, by using a camera system that can track the fluorescence signal in each tube. The results were applied to construct the standard curves and then were used for calculating the cDNA copies.

\section{Statistical analysis}

Data were analyzed using SPSS 16.0 software (SPSS, Inc., Chicago, IL, USA). Chi-squared test was used to identify the differences in $h M A M(+)$ expression in various groups. A $P$-value $<0.05$ was considered statistical significance.

\section{Ethical consideration}

The study protocol was approved by the Institutional Review Board of the Ministry of Health and Hanoi Medical University (3018/QD-BYT). Informed consent was obtained from all patients before the experiment. This study was conducted in accordance with the Declaration of Helsinki.

\section{Results}

After cloning the cDNA of $h M A M$ by PCR from four breast cancer cell lines, KPL4, MCF7, BT474 cell lines were positive and the MDA-MB231 cell line was negative (Figure 1) for the presence of the gene.

Standard curves were developed using 20,000 BT474 cell lines. Concentrations of PCR were obtained at $\sim 679$ ng. According to the formula, the number of cDNA copies of $h M A M$ generated from the breast cancer cell line BT474 was $10^{5}$. Based on this standard, it is possible to calculate the number of copies of $h M A M$ mRNA (Figure 2).

Figure 3 shows the sequencing of the PCR products to confirm that the amplified gene sample was a copy of the $h M A M$ gene, which was published in the gene bank.

Standard curves were made by measuring crossing point (CP) values (Figure 4) in six reaction tubes. Tube $h M A M$ cDNA $1 \times$ was generated from 20,000 BT474 cells, which was equivalent to $10^{5}$ copies. At a dilution of 100 times, which equaled to 200 breast cancer cells, the copies were detected

Table I Sequences of primers used in this study

\begin{tabular}{|l|l|l|l|}
\hline Primer & Sequences & Temperature ('⿳) & Length (bp) \\
\hline GAPDH F & 5'-CGG AGT CAA CGG ATT TGG TCG TAT-3' & 65.3 & 307 \\
GAPDH R & 5'-AGC CTT CTC CAT GGT GGT GAA GAC-3' & 67 & \\
hMAM F & 5'-CTC CCA GCA CTG CTA CGC AGG CTC-3' & 67.2 & 202 \\
hMAM R & $5^{\prime}$-CAC CTC AAC ATT GCT CAG AGT TTC ATC CG-3' & 66.3 & \\
\hline
\end{tabular}

Abbreviation: hMAM, human mammaglobin mRNA. 


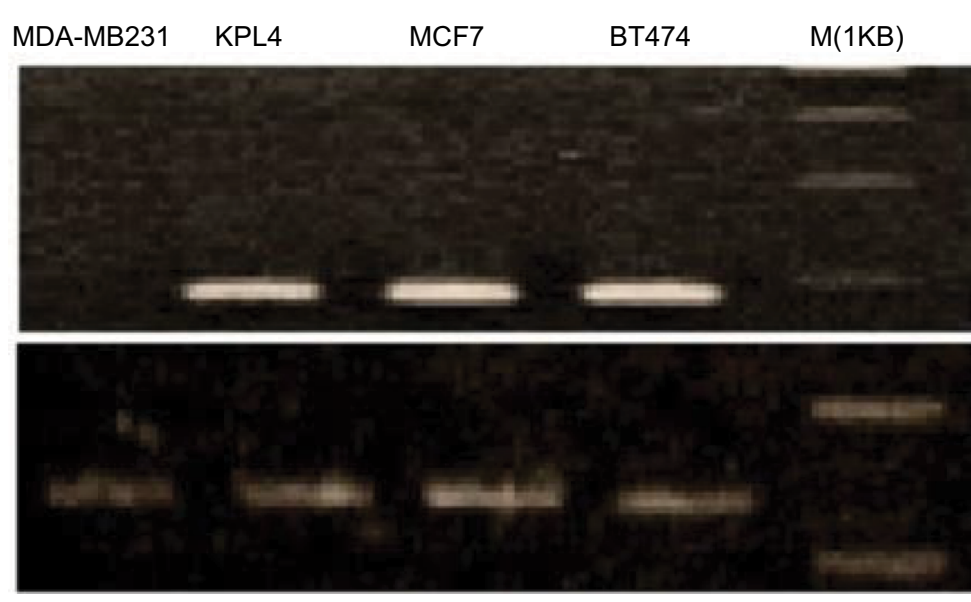

hMAM 202 bp

GADPH 307 bp

Figure I Electrophoresis image of polymerase chain reaction cDNA of $h M A M$ and GAPDH in breast cancer cells. Abbreviation: hMAM, human mammaglobin mRNA.

with the CP at 33.14 and the number of copies at 893 . Less $C P$ value had higher number of cDNA copies.

Table 2 shows that $h M A M$ mRNA transcription was detected in $83.7 \%$ of the breast cancer tissues and in blood of $53.5 \%$ of breast cancer patients, while it was detected in only $9.5 \%$ of the fibrosis tissues and $0 \%$ in blood of fibrosis patients.

Table 3 reveals that $h M A M \mathrm{mRNA}$ in the peripheral blood of breast cancer patients increased with tumor size, stage of cancer and distant metastasis $(P<0.05)$. We did not find any differences in $h M A M$ mRNA in the breast cancer tissue.

\section{Discussion}

In this study, RT-PCR technology allows to investigate low levels of mRNA that cannot be detected by other classical methods such as the northern blot. ${ }^{15}$ RT-PCR is often considered the most sensitive test for detecting molecular markers of tumors. ${ }^{16}$ RT-PCR also provides a high specificity with the design of specific genes of interest.

The synthesis of cDNA based on RNA was performed by reverse enzymes. After cDNA synthesis, cDNA quality was tested by the amplification of $G A P D H$ (internal standard) gene with specific primers. $G A P D H$ is present in every cell of the body and is often used to test the quality of cDNA, eliminating false-negative cases due to poor quality of cDNA. After the amplification reaction, if the quality of the cDNA is poor or cDNA is contaminated, the electrophoretic band on agarose will be blurred and other sub-bands will appear. Our results showed that the PCR product with GADPH F/R primers showed a dark light band with the size of about 307 bp, as expected. This demonstrates that RNA quality and cDNA syntheses were successful, and the cDNA produced met the conditions that were required for subsequent $h M A M$ gene replication.

Initial trials were performed on four breast cancer cell lines, MCF-7, KPL-4, BT-474 and MDA-MB231. hMAM was expressed in three out of the four breast cancer cell lines, except MDA-MB231. It has been argued that none of the genes are expressed in all breast cancer cell lines, but the cancer cell line remains the fundamental for cancer research. ${ }^{17,18}$

$h M A M$ is one of 23 members of the secretoglobin-uteroglobin family. With northern blot and RT-PCR techniques, $h M A M$ was detected in $90 \%$ malignant breast cancer tissues, while it was not detected in benign breast tissue or healthy breast tissue or was detectable at very low levels. ${ }^{19}$ Of 43 breast cancer samples, 36 cases $(83.7 \%)$ showed $h M A M$ mRNA replication. This result is in line with previous studies. According to Raica et al, using RT-PCR, the detection rate for $h M A M$ in primary breast cancer was $78.7 \% .{ }^{20}$ According to Al Joudi, the detection rate of $h M A M$ mRNA in breast cancer tissue was $90 \% .{ }^{19}$ With a very high detection rate in breast cancer, $h M A M$ mRNA is the perfect marker for breast cancer diagnosis. Detection of $h M A M$ in breast cancer tissue is an important positive finding for the expression of $h M A M$ mRNA in CTCs. Meanwhile, in the non-cancer control group in the study (ie, fibrous tissue), after performing the RT-PCR technique, only two samples (9.5\%) showed $h M A M$ mRNA replication, which was much lower than that in the breast cancer patients.

The rate of expression of $h M A M$ mRNA in the breast cancer tissue was very high. Among cases with very small tumor (ie, $<2 \mathrm{~cm}-\mathrm{T} 1$ ), $90 \%$ cases were found to have $h M A M$ mRNA copies. $h M A M$ mRNA copies were found in $87.5 \%$ cases among patients in Phase I (very early stage) and 76.7\% 
Amplification curves

\begin{tabular}{llllll}
\hline$-1: \mathrm{H}_{2} \mathrm{O}$ & $-2: 1 \times$ & $-3: 10 \times$ & $-4: 100 \times$ & $-5: 1000 \times$ & $-6: 10000 \times$ \\
\hline
\end{tabular}
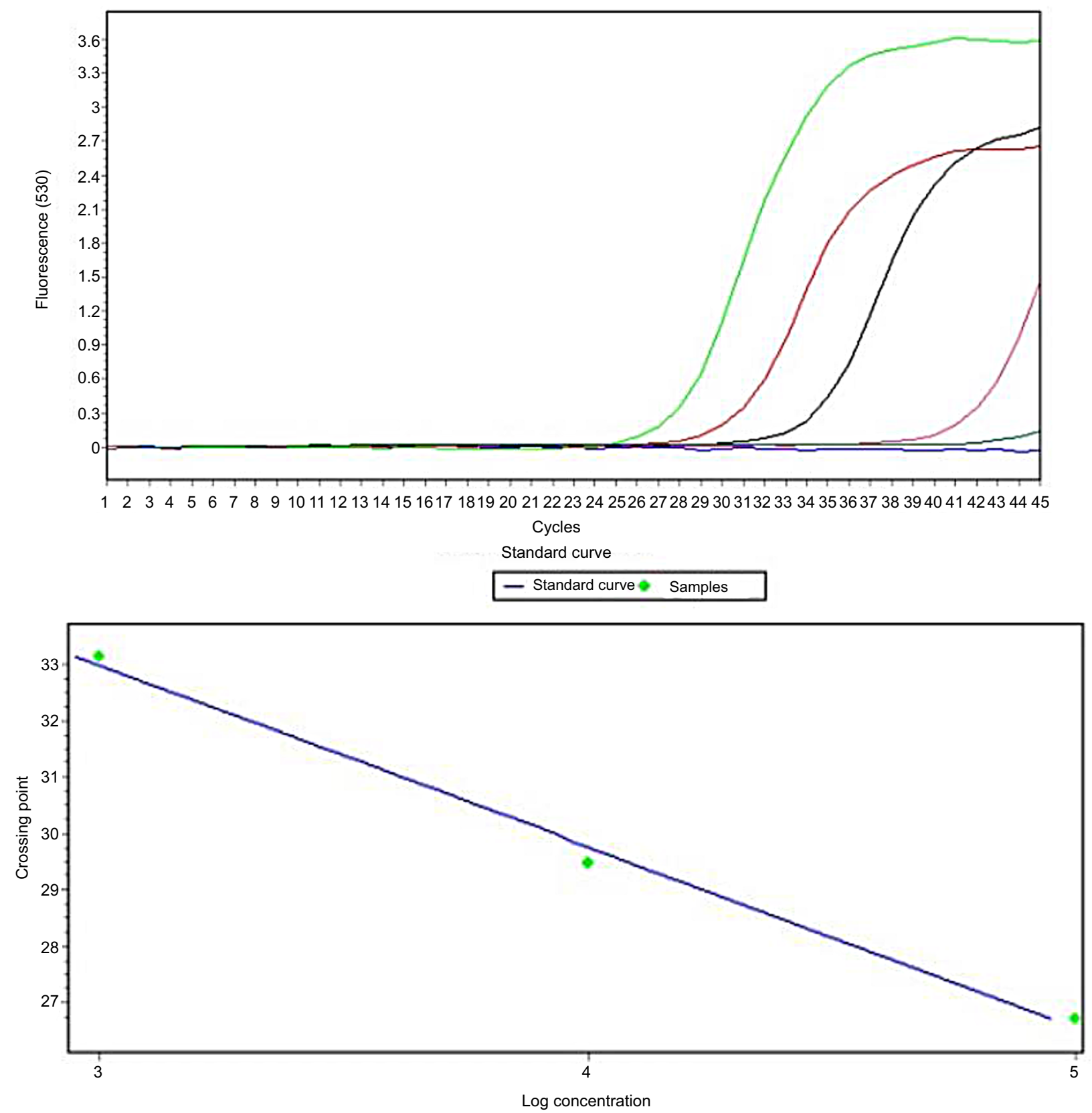

Figure 2 Real-time PCR for cDNA of $h M A M$ to determine the standard curve using BT474 cell lines. Abbreviation: hMAM, human mammaglobin mRNA; PCR, polymerase chain reaction.

of patients with the absence of lymph node metastases. This suggests that $h M A M$ replication is present in the tumor tissue at the early stage and the $h M A M$ mRNA in tissues may be used for early diagnosis of breast cancer. Results showed no statistically significant difference in the incidence of $h M A M$ mRNA expression with tumor size, lymph node metastasis, distant metastasis and stage of disease. Roncella et al, study- ing 148 breast cancer samples, showed that the incidence of $h M A M$ mRNA in breast cancer patients was $63 \%, 56 \%$ and $100 \%$ among patients having tumor size of $<2,2-5$ and $>5 \mathrm{~cm}$, respectively. ${ }^{21}$ The authors did not find any differences in the presence of $h M A M$ mRNA in age, histopathologic and lymph node status. ${ }^{21}$ Al-Joudi et al found that the detection rate of $h M A M$ mRNA in breast cancer was not related to tumor size, 

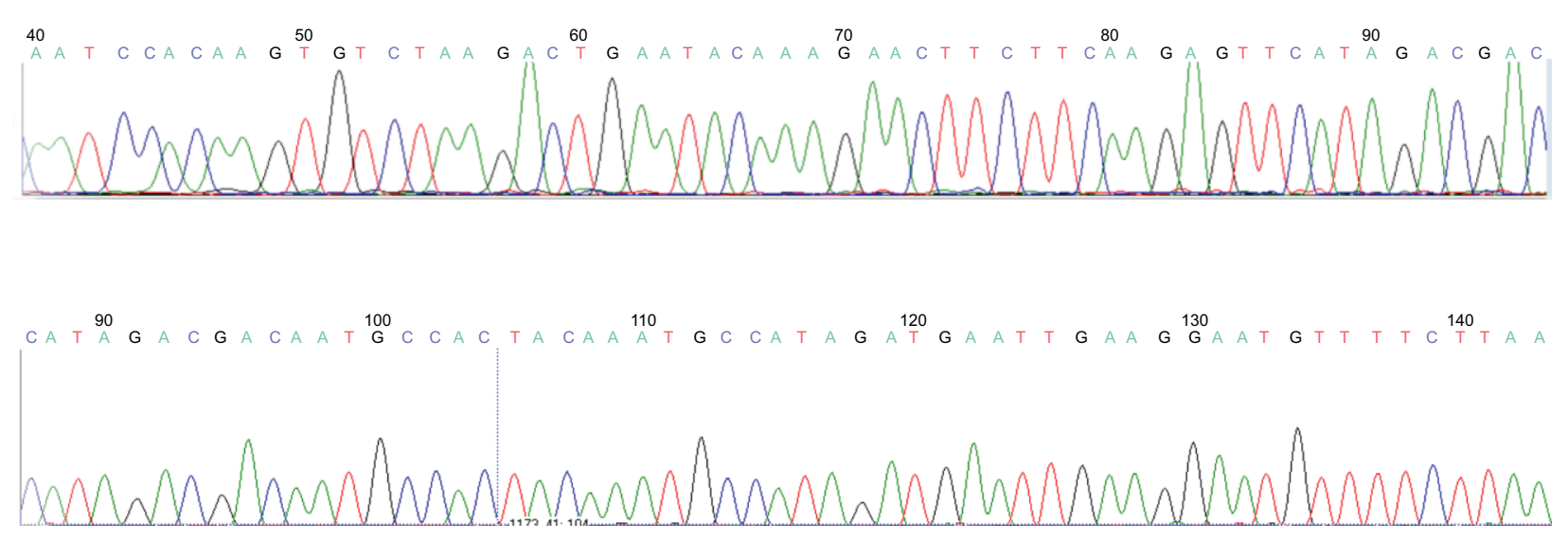

Figure 3 Sequences of $h M A M$ gene in PCR positive.

Abbreviation: hMAM, human mammaglobin mRNA; PCR, polymerase chain reaction.

\begin{tabular}{|c|c|c|c|c|c|c|c|c|}
\hline \multicolumn{9}{|c|}{ Setting } \\
\hline & \multirow{2}{*}{$\begin{array}{l}\text { Channel } \\
\text { Program }\end{array}$} & 530 & Color compensation Off & \multirow{2}{*}{\multicolumn{3}{|c|}{ Method Automated (F“ max) }} & \multirow[b]{2}{*}{ Units } & \\
\hline & & \multicolumn{2}{|l|}{ Cycles } & & & & & \\
\hline \multicolumn{9}{|c|}{ Results } \\
\hline Inc & Pos & Name & & Type & $\mathrm{CP}$ & \multicolumn{2}{|c|}{ Concentration } & Standard \\
\hline$\nabla$ & 1 & $\mathrm{H} 2 \mathrm{O}$ & & Unknown & & & & \\
\hline$\nabla$ & 2 & $1 x$ & & Standard & 26.72 & & $3 E 4$ & 1.00E5 \\
\hline$\nabla$ & 3 & $10 x$ & & Standard & 29.46 & & 25E4 & 1.00E4 \\
\hline$\nabla$ & 4 & $100 x$ & & Standard & 33.14 & & $3 \mathrm{E} 2$ & $1.00 \mathrm{E} 3$ \\
\hline$\nabla$ & 5 & $1000 x$ & & Standard & $>40.00$ & $<6.5$ & OEO & $1.00 \mathrm{E} 2$ \\
\hline$\nabla$ & 6 & $10000 x$ & & Standard & $>40.00$ & $<6.5$ & OEO & 1.00E1 \\
\hline
\end{tabular}

Figure 4 Real-time PCR for hMAM cDNA determined the detection level in BT474 cell lines.

Abbreviation: CP, crossing point; hMAM, human mammaglobin mRNA; PCR, polymerase chain reaction.

Table 2 hMAM mRNA transcription in the study

\begin{tabular}{|l|l|l|}
\hline Samples & Samples (n) & $\begin{array}{l}\text { hMAM mRNA (+), } \\
\text { n/N (\%) }\end{array}$ \\
\hline Breast cancer tissue & 43 & $36 / 43(83.7 \%)$ \\
Fibrosis tissue & 21 & $2 / 21(9.5 \%)$ \\
Peripheral blood in breast & 43 & $23 / 43(53.5 \%)$ \\
cancer patients & & $0 / 21(0 \%)$ \\
Peripheral blood in fibrosis & 21 & \\
patients & & \\
\hline
\end{tabular}

Abbreviation: hMAM, human mammaglobin mRNA.

marital status, family history of breast cancer and the presence of PR, ER, HER endocrine receptors. ${ }^{22}$ Thus, $h M A M$ mRNA was detected at an early stage of breast cancer with high rates. This result implies the potential use of $h M A M$ mRNA as a new marker contributing to the diagnosis of breast cancer.

On comparing the detection rate of $h M A M$ mRNA in the peripheral blood of patients with breast cancer, we found that the expression of $h M A M$ mRNA in the blood was related to the disease stage, tumor size and distant metastasis. Research shows that by detecting $h M A M$ mRNA replication, breast cancer cells in the blood can be found in the early stage when the tumor is small, without clinical metastases. According to Lee et al, the rate of $h M A M$ mRNA detection in peripheral blood in the first and second stages was $23.4 \%$ and in the third and fourth stages was $82.9 \%$. The $h M A M$ mRNA expression rate in the blood was related to lymph node metastasis, distant metastasis and endocrine receptors. ${ }^{23}$ Nakagawa et al detected CTCs in $29 \%$ cases with stage I, $45 \%$ cases with stage II and $77 \%$ cases with stage III. ${ }^{24}$ Grünewald et al demonstrated that $h M A M$ mRNA level was associated with tumor size and lymph node metastases, while no association was found for other genes. ${ }^{12}$

In this study, RT-PCR was conducted with breast cancer cell lines, breast cancer tissues, peripheral blood of breast cancer patients and breast tissues of patients with breast fibroids in order to detect the differences in $h M A M$ mRNA in both groups of patients. On comparing to Gene Bank, we found that $h M A M$ mRNA expression levels in both groups were similar. The similarity was $100 \%$ with $h M A M$ gene published in the International GenBank with codes AY893203, AY888136 and U33147. We supposed that the expression of $h M A M$ mRNA found in breast cancer patients is an over- 
Table 3 hMAM expression in the breast cancer tissue and blood according to different characteristics

\begin{tabular}{|c|c|c|c|c|c|c|c|}
\hline \multirow[t]{2}{*}{ Characteristics } & \multirow[t]{2}{*}{ Cases (n) } & \multicolumn{3}{|c|}{ hMAM (+) in breast cancer tissues } & \multicolumn{3}{|c|}{$\begin{array}{l}\text { hMAM }(+) \text { in peripheral blood of } \\
\text { breast cancer patients }\end{array}$} \\
\hline & & $\mathbf{n}$ & $\%$ & $P$-value & $n$ & $\%$ & $P$-value \\
\hline \multicolumn{8}{|l|}{ Age (years) } \\
\hline$\leq 50$ & 21 & 16 & 76.2 & 0.19 & 10 & 47.6 & 0.45 \\
\hline$>50$ & 22 & 20 & 90.9 & & 13 & 59.1 & \\
\hline \multicolumn{8}{|l|}{ Tumor size } \\
\hline TI & 10 & 9 & 90.0 & 0.50 & 3 & 30.0 & 0.02 \\
\hline $\mathrm{T} 2$ & 17 & 13 & 76.5 & & 7 & 41.2 & \\
\hline $\mathrm{T} 3$ and $\mathrm{T} 4$ & 16 & 14 & 87.5 & & 13 & 81.2 & \\
\hline \multicolumn{8}{|c|}{ Distant metastasis } \\
\hline Mo & 38 & 31 & 81.6 & 0.29 & 18 & 47.4 & 0.03 \\
\hline MI & 5 & 5 & 100.0 & & 5 & 100.0 & \\
\hline \multicolumn{8}{|l|}{ Lymph node } \\
\hline No & 13 & 10 & 76.9 & 0.40 & 5 & 38.5 & 0.19 \\
\hline Yes & 30 & 26 & 86.7 & & 18 & 60.0 & \\
\hline \multicolumn{8}{|l|}{ Stage of cancer } \\
\hline I & 8 & 7 & 87.5 & 0.75 & 2 & 25.0 & 0.01 \\
\hline II & 19 & 15 & 78.9 & & 8 & 42.1 & \\
\hline III and IV & 16 & 14 & 87.5 & & 13 & 81.2 & \\
\hline \multicolumn{8}{|c|}{ Histopathology type } \\
\hline Ductal & 29 & 27 & 93.1 & 0.06 & 16 & 55.2 & 0.52 \\
\hline Lobular & 8 & 5 & 62.5 & & 3 & 37.5 & \\
\hline Mucus & 6 & 4 & 66.7 & & 4 & 66.7 & \\
\hline \multicolumn{8}{|l|}{ CAI5-3 (U/mL) } \\
\hline$\leq 32$ & 33 & 29 & 84.4 & 0.50 & 16 & 48.5 & 0.23 \\
\hline$>32$ & 10 & 7 & 70.0 & & 7 & 70.0 & \\
\hline
\end{tabular}

Abbreviation: hMAM, human mammaglobin mRNA.

replication of the mRNA, resulting in increased synthesis of mammaglobin protein, which might be the cause of tumor cell growth. In fact, using RT-PCR, Watson et al did not find $h M A M$ expression in different benign tissues or in tumors that are only found in breast cancer. ${ }^{25}$ Therefore, we assumed that the $h M A M$ mRNA abnormalities in women with breast cancer were not inherited, even after they migrated to other societies. However, further studies are needed to understand clearly the mechanism of this gene in next generations in order to develop appropriate prevention strategies.

Standard curves were developed based on the breast cancer cell lines with enhanced gene copying. According to the RT-PCR results, BT474 cell lines detected $h M A M$ mRNA replication, which can be used to construct the curve. After counting the number of specific cells per milliliter, we performed total RNA synthesis and generated cDNA using PCR with $h M A M$ primer. The product mass measurement obtained from the PCR reaction was the amplified $h M A M$ gene. Based on the formula to transform the product mass to the number of copies of the $h M A M$ gene after amplification, we divided it by $2^{12}$ ( 25 was the number of PCR cycles) to compute the number of copies of the $h M A M$ cDNA extracted from 20,000 BT474 cells at the first stage. At the 100-fold dilution equivalent to 200 breast cancer cells and CP equal to $33,14,893$ copies were identified as the lowest threshold that could detect $h M A M$ replication. According to Zehentner et al, by using RT-PCR technique to mix BT474 breast cancer cell lines with $5 \mathrm{~mL}$ of blood from healthy people, the detection threshold was 100 BT474 cells/mL of blood, and the detectable copy threshold was greater than $1,000 .{ }^{26}$

The strengths of this study included the development of a procedure to detect $h M A M \mathrm{mRNA}$ from the breast cancer tissue and peripheral blood of breast cancer patients. The results show that $h M A M$ could be detected in the blood at a very early stage. This could be the initial step to monitor treatment of breast cancer along with other markers, actively contributing to the diagnosis and treatment of breast cancer. Meanwhile, small sample size in this study could reduce the representativeness of the population to the entire population of women with breast cancer in Vietnam.

\section{Conclusion}

In summary, the results of the study provide an overall picture of the replication of $h M A M$ mRNA in breast cancer, suggesting the role of $h M A M$ mRNA in breast cancer molecular pathology. 


\section{Disclosure}

The authors report no conflicts of interest in this work.

\section{References}

1. Dieu B, Duc NB, Thuan TV. Cancer challenges and national cancer control programs to 2020. Viet Nam J Oncol. 2012;4(13):13-18.

2. Jenkins C, Minh LN, Anh TT, et al. Breast cancer services in Vietnam: a scoping review. Glob Health Action. 2018;11(1):1435344.

3. Li G, Zhang J, Jin K, et al. Human mammaglobin: a superior marker for reverse-transcriptase PCR in detecting circulating tumor cells in breast cancer patients. Biomark Med. 2011;5(2):249-260.

4. Cristofanilli M, Budd GT, Ellis MJ, et al. Circulating tumor cells, disease progression, and survival in metastatic breast cancer. $N$ Engl J Med. 2004;351(8):781-791.

5. Cristofanilli M, Hayes DF, Budd GT, et al. Circulating tumor cells: a novel prognostic factor for newly diagnosed metastatic breast cancer. J Clin Oncol. 2005;23(7):1420-1430.

6. Xenidis N, Ignatiadis M, Apostolaki S, et al. Cytokeratin-19 mRNApositive circulating tumor cells after adjuvant chemotherapy in patients with early breast cancer. J Clin Oncol. 2009;27(13):2177-2184.

7. Lacroix M. Significance, detection and markers of disseminated breast cancer cells. Endocr Relat Cancer. 2006;13(4):1033-1067.

8. Stathopoulou A, Gizi A, Perraki M, et al. Real-time quantification of CK-19 mRNA-positive cells in peripheral blood of breast cancer patients using the LightCycler system. Clin Cancer Res. 2003;9(14):5145-5151.

9. Ring AE, Zabaglo L, Ormerod MG, Smith IE, Dowsett M. Detection of circulating epithelial cells in the blood of patients with breast cancer: comparison of three techniques. Br J Cancer. 2005;92(5):906-912.

10. van der Auwera I, Peeters D, Benoy IH, et al. Circulating tumour cell detection: a direct comparison between the CellSearch System, the AdnaTest and CK-19/mammaglobin RT-PCR in patients with metastatic breast cancer. Br J Cancer. 2010;102(2):276-284.

11. Zhao S, Liu Y, Zhang Q, et al. The prognostic role of circulating tumor cells (CTCs) detected by RT-PCR in breast cancer: a meta-analysis of published literature. Breast Cancer Res Treat. 2011;130(3):809-816.

12. Grünewald K, Haun M, Urbanek M, et al. Mammaglobin gene expression: a superior marker of breast cancer cells in peripheral blood in comparison to epidermal-growth-factor receptor and cytokeratin-19. Lab Invest. 2000;80(7):1071-1077.

13. Ntoulia M, Stathopoulou A, Ignatiadis M, et al. Detection of mammaglobin A-mRNA-positive circulating tumor cells in peripheral blood of patients with operable breast cancer with nested RT-PCR. Clin Biochem. 2006;39(9):879-887.

14. Wang Z, Spaulding B, Sienko A, et al. Mammaglobin, a valuable diagnostic marker for metastatic breast carcinoma. Int J Clin Exp Pathol. 2009;2(4):384-389.
15. Grover PK, Cummins AG, Price TJ, Roberts-Thomson IC, Hardingham JE. Circulating tumour cells: the evolving concept and the inadequacy of their enrichment by EpCAM-based methodology for basic and clinical cancer research. Ann Oncol. 2014;25(8):1506-1516.

16. Jaeger BAS, Jueckstock J, Andergassen U, et al. Evaluation of two different analytical methods for circulating tumor cell detection in peripheral blood of patients with primary breast cancer. Biomed Res Int. 2014;2014(7):1-11.

17. Fabisiewicz A, Kulik J, Kober P, Brewczyńska E, Pieńkowski T, Siedlecki JA. Detection of circulating breast cancer cells in peripheral blood by a two-marker reverse transcriptase-polymerase chain reaction assay. Acta Biochim Pol. 2004;51(3):747-755.

18. Chekhun S, Bezdenezhnykh N, Shvets J, Lukianova N. Expression of biomarkers related to cell adhesion, metastasis and invasion of breast cancer cell lines of different molecular subtype. Exp Oncol. 2013;35(3):174-179.

19. Al Joudi FS. Human mammaglobin in breast cancer: a brief review of its clinical utility. Indian J Med Res. 2014;139(5):675-685.

20. Raica M, Cîmpean AM, Meche A, Alexa A, Suciu C, Mureşan A. Analysis of the immunohistochemical expression of mammaglobin A in primary breast carcinoma and lymph node metastasis. Rom J Morphol Embryol. 2009;50(3):341-347.

21. Roncella S, Ferro P, Bacigalupo B, et al. Relationship between human mammaglobin mRNA expression in breast cancer tissue and clinico-pathologic features of the tumors. J Exp Clin Cancer Res. 2006;25(1):65-72.

22. Al-Joudi FS, Kaid FAK, Ishak I, Mohamed N, Osman K, Alias IZ. Expression of human mammaglobin and clinicopathologic correlations in breast cancer: the findings in Malaysia. Indian J Pathol Microbiol. 2011;54(2):284-289.

23. Lee G-W, Kim J-Y, Koh E-H, et al. Plasma human mammaglobin mRNA associated with poor outcome in patients with breast cancer. Genet $\mathrm{Mol}$ Res. 2012;11(4):4034-4042.

24. Nakagawa T, Martinez SR, Goto Y, et al. Detection of circulating tumor cells in early-stage breast cancer metastasis to axillary lymph nodes. Clin Cancer Res. 2007;13(14):4105-4110.

25. Watson MA, Darrow C, Zimonjic DB, Popescu NC, Fleming TP. Structure and transcriptional regulation of the human mammaglobin gene, a breast cancer associated member of the uteroglobin gene family localized to chromosome 11q13. Oncogene. 1998;16(6):817-824

26. Zehentner BK, Persing DH, Deme A, et al. Mammaglobin as a novel breast cancer biomarker: multigene reverse transcription-PCR assay and sandwich ELISA. Clin Chem. 2004;50(11):2069-2076.
Breast Cancer - Targets and Therapy

\section{Publish your work in this journal}

Breast Cancer - Targets and Therapy is an international, peerreviewed open access journal focusing on breast cancer research, identification of therapeutic targets and the optimal use of preventative and integrated treatment interventions to achieve improved outcomes, enhanced survival and quality of life for the cancer patient.

\section{Dovepress}

The manuscript management system is completely online and includes a very quick and fair peer-review system, which is all easy to use. Visit http://www.dovepress.com/testimonials.php to read real quotes from published authors. 